\title{
GREEN SYNTHESIS OF SILVER NANOPARTICLES USING A MOUNTAIN PLANT EXTRACT
}

\author{
Mohammad Hasan ROUSTA and Nahid GHASEMI ${ }^{\mathrm{a},{ }^{*}}$

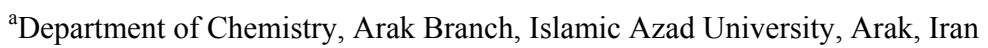

Received November 3, 2017

\begin{abstract}
The present study investigated the synthesis of silver nanoparticles (Ag-NPs) using Artemisia Sieberi Besser leaf extract. To evaluate parameters affecting the synthesis including $\mathrm{pH}$, volume of extract, concentration of silver nitrate solution, temperature and time, Ultraviolet-Visible (UV-Vis) spectroscopy was used. Ag-NPs were characterized by UV-Vis spectroscopy, Scanning electron microscopy (SEM), X-ray diffraction spectroscopy (XRD), Fourier transform infrared spectroscopy (FTIR) and Transmission Electron Microscopy (TEM) techniques. The SEM revealed spherical morphology of the particles with the size around 41-88 nm. The XRD pattern of Ag-NPs confirmed that these nanoparticles were crystalline and had cubic structure with an average size of 20 $\mathrm{nm}$. TEM analysis of synthesized nanoparticles showed spherical and cubic particles with an average size of $20 \mathrm{~nm}$. The results showed that silver nanoparticles could be produced by an eco-friendly biological method with no need to any harmful chemicals using Artemisia Sieberi Besser (a mountain plant) extract.

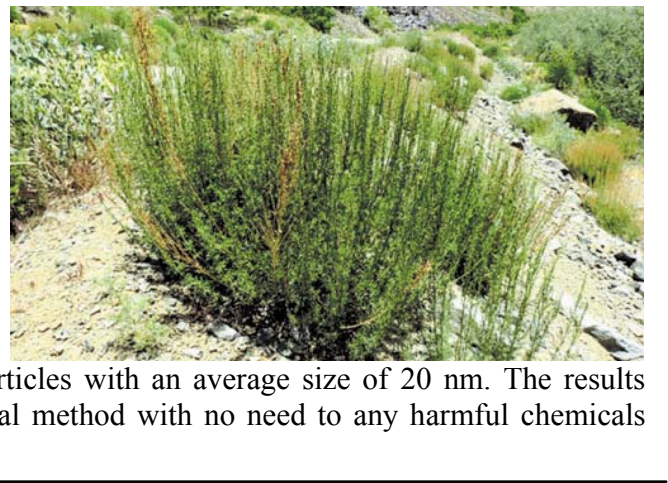

\section{INTRODUCTION}

Artemisia Sieberi Besser (synonym of Artemisia herba alba) or "desert worm wood", also known as 'Dermaneh', is an endemic species in Iran. It belongs to the Asteraceae family. ${ }^{1}$ Artemisia species have practical applications in traditional medicine as drugs and food for coughs, colds, intestinal worms treatment, and wounds healing. Moreover, it is a useful remedy for the diabetes mellitus treatment in Iraq $^{2}$. Some biological activities of A. Sieberi like antifungal activities, antimicrobial, antinociceptive effect, and insecticidal activity were confirmed. ${ }^{3-14}$ The Artemisia genus have more than 160 individual components, including santonin, flavonoids, luteolin, apigenin, flavones, davanone, sesquiterpene lactones and bicyclic monoterpene glycosides ${ }^{15}$ and related compounds, cyclic sesquiterpenes ${ }^{16}$ and artemisinin. ${ }^{17}$ Dermaneh is a well-known medicinal plant in Iran. Nowadays, nanotechnology belongs to the large improvement of human life and it has a multidisciplinary research area. Amongst the different fields of nanotechnology, green nanotechnology provides more effective synthesis route with expected products and economical manner for nanoparticles. ${ }^{18}$ Nanomaterials, due to their electrical, optical, magnetic and chemical properties compared to the bulk materials, are new, emerging and creating development. Many physical, chemical and biological methods are adopted for nanoparticles synthesizing. Physical and chemical factors including the shape and size of nanoparticles as well as $\mathrm{pH}$ and temperature of the reaction mixture were controlled during the nanoparticles synthesis. ${ }^{19}$

In recent years, biological synthesis of metal nanoparticles was achieved using bacteria, ${ }^{20}$ algae, ${ }^{21,22}$ fungi ${ }^{23,24}$ and plants. ${ }^{25}$ Green synthesis of metal nanoparticles by extracellular plants and herbal compounds is more eco-friendly, requires low cost and less time, and leads to large-scale

\footnotetext{
*Corresponding author: n-ghasemi@iau-arak.ac.ir; anahid3@gmail.com; Tel: +98 86334135421
} 
yields. Plant mediated synthesis route has more advantages compared to the chemical and microbe mediated synthesis method due to the elimination of the culture maintaining process. ${ }^{26,27}$ Flavonoids, polyphenols and alkaloids compounds which are found in plants may reduce metal ions to metal nanoparticles and act as stabilizing and capping agents. $^{28}$

As mentioned above, Artemisia plant is full of many compounds, such as flavonoids. So, this study investigated the efficiency of this plant in the synthesis of metal nanoparticles. To this end, silver was selected because of its unique properties. Silver is a transition metal and prehistoric among the noble metals, which has been widely used for thousands of years in human history and acted as a health additive in traditional Indian and Chinese Ayurvedic medicine. ${ }^{29}$ Silver nanoparticles have many applications in biomedicine because of their large surface area compared to the bulk materials. ${ }^{30}$

In this work, the optimum conditions for silver nanoparticles synthesis like silver ion concentration, temperature and $\mathrm{pH}$ were determined by analyzing the absorbance spectra acquired by an UV-Vis spectrophotometer. To analyze the crystal size, phase composition, morphology and structure, Scanning Electron Microscope (SEM), X-ray diffraction spectroscopy (XRD) Transmission Electron Microscopy (TEM), and Fourier Transform Infrared (FTIR) Spectroscopy were used as silver nanoparticles characterization techniques.

\section{MATERIALS AND METHODS}

Chemicals such as silver nitrate $(1 \mathrm{mM})$, hydrochloric acid $(0.1 \mathrm{M})$, and sodium hydroxide $(0.1 \mathrm{M})$ were purchased from Sigma-Aldrich or Merck and Dermaneh leaves (Fig. 1) were collected from Khozestan province, Iran.

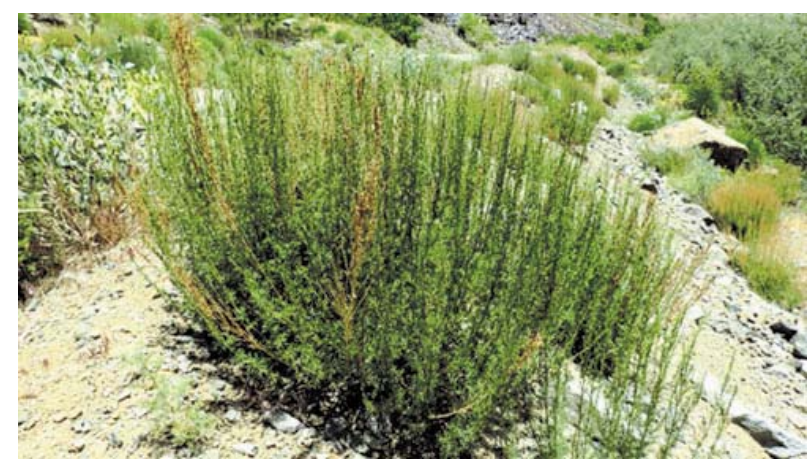

Fig. 1 - Artemisia sieberi Besser (Dermaneh) plant.

\section{Preparation of Leaf Extract}

To prepare the leaf extract, $20 \mathrm{~g}$ of leaves was washed thoroughly with double distilled water for three times. Then, the leafs were sliced into small pieces and boiled in $200 \mathrm{~mL}$ double distilled water at $60{ }^{\circ} \mathrm{C}$ for $30 \mathrm{~min}$. After that, the extract was filtered through Whatman No.1 filter paper; the extract solution was collected and stored at $4{ }^{\circ} \mathrm{C}$ for further nanoparticles' synthesis process.

\section{Synthesis of Silver Nanoparticles}

For typical synthesis process of silver nanoparticles, $5 \mathrm{~mL}$ of leaf extract was added to 95 $\mathrm{ml}$ of $1 \mathrm{mM}$ silver nitrate aqueous solution and incubated at room temperature. The solution' color changed to brown, indicating synthesis of silver nanoparticles (Fig. 2). To investigate the optimum parameters for silver nanoparticles synthesis, the experiments were carried out at different $\mathrm{pH}$ values $(2,4,6,8$ and 10), volumes of the extract $(2,4,6$ and $8 \mathrm{~mL})$, silver ion concentrations $(0.001,0.003$, 0.005 and $0.01 \mathrm{mM})$, temperature $(25,35,65,70$ and $\left.80{ }^{\circ} \mathrm{C}\right)$ and time $(10,25,45,65,100,1020$, $1320 \mathrm{~min}$ ). In order to investigate the effect of these parameters on silver nanoparticles synthesis, $\mathrm{UV}-\mathrm{Vis}$ spectrophotometer was used (UV-Vis Agilent - 8541 was setup at wavelengths of 330 $800 \mathrm{~nm}$ ).

\section{Effect of pH on silver nanoparticle synthesis using Dermaneh extract}

$5 \mathrm{~mL}$ Dermaneh extract and $0.001 \mathrm{M}$ silver nitrate solution $(95 \mathrm{ml})$ were added to 5 Erlenmeyer flasks. $\mathrm{pH}$ of each Erlenmeyer flask was adjusted at 2, 4, 6, 8 and 10 using $0.1 \mathrm{M}$ sodium hydroxide and $0.1 \mathrm{M}$ hydrochloric acid. $\mathrm{pH}$ of the reaction mixtures was determined using digital $\mathrm{pH}$ meter (EDT GP353 pH meter). Then, the solution was stirred at the stirring rate of 150 rpm for $30 \mathrm{~min}$ at room temperature. By adding the metallic salt solution, the color of solution obviously changed from light yellow to dark brown, indicating the formation of silver nanoparticles. After that, UV-Vis spectrum was taken in the range of $330-800 \mathrm{~nm}$ and the best $\mathrm{pH}$ value for this synthesis was determined and established for further experiments. 

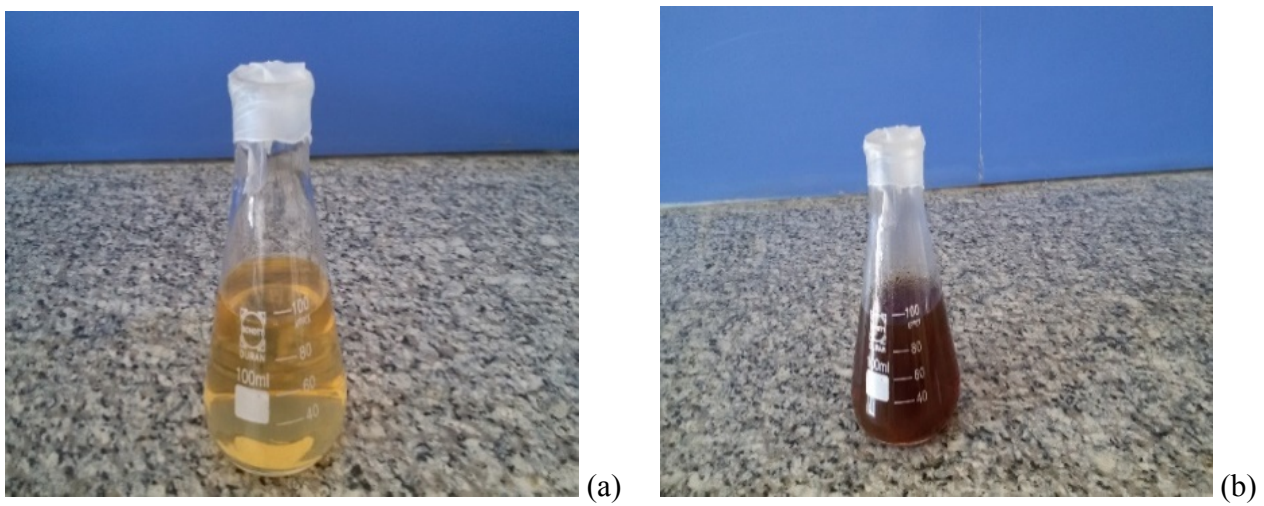

Fig. 2 - a) Dermaneh leaf extract solution, b) Colour of the Dermaneh extract solution after reaction with $\mathrm{AgNO}_{3}$.

\section{Effect of Dermaneh extract volume on silver nanoparticle synthesis}

$95 \mathrm{~mL}$ of $0.001 \mathrm{M}$ silver nitrate was poured into 4 Erlenmeyer flasks and 2, 4, 6 and $8 \mathrm{~mL}$ of Dermaneh extract solution were added to them. Then, $\mathrm{pH}$ of all Erlenmeyer flasks was adjusted at the optimized $\mathrm{pH}$ and the solution was stirred at the stirring rate of $150 \mathrm{rpm}$ for $30 \mathrm{~min}$ at room temperature. After that, UV-Vis spectra were recorded like in the previous step. Thus, the best volume of extract has been determined and used for further experiments.

\section{Effect of metal salt concentration on silver nanoparticle synthesis by Dermaneh extract}

In order to optimize the concentration of the metal salt solution, $8 \mathrm{~mL}$ of Dermaneh extract was poured into 4 Erlenmeyer flasks, then $5 \mathrm{~mL}$ of $0.001,0.003,0.005$ and $0.01 \mathrm{M}$ silver nitrate was added to them. The $\mathrm{pH}$ of all Erlenmeyer flasks was adjusted to the optimized $\mathrm{pH}$, and after a while, these solutions were stirred at the stirring rate of $150 \mathrm{rpm}$ for $30 \mathrm{~min}$ at room temperature. Then, UV-Vis spectrum was taken from them in the range of $330-800 \mathrm{~nm}$ and the best concentration was determined and used for next experiments.

\section{Effect of temperature on silver nanoparticle synthesis by Dermaneh extract}

Like in the previous steps, the optimal temperature was measured. $8 \mathrm{~mL}$ of Dermaneh extract and $95 \mathrm{~mL}$ silver nitrate $(0.01 \mathrm{M})$ were poured into 7 Erlenmeyer flasks and $\mathrm{pH}$ was set at 10. Then all Erlenmeyer flasks were placed in the oven at temperatures of $25,35,70$ and $80{ }^{\circ} \mathrm{C}$ for
1 hour. After that, all samples were centrifuged and UV-Vis spectra were recorded with the same conditions as before. So the optimal temperature was obtained.

\section{Effect of time on silver nanoparticle synthesis by Dermaneh extract}

Determining the appropriate time for silver nanoparticles synthesis is an important step because metal ions are increased and released at specific time. Then the surface plasmon resonance would be decreased. $8 \mathrm{~mL}$ of the Dermaneh extract and $95 \mathrm{~mL}$ silver nitrate $(0.01 \mathrm{M})$ were poured into 7 Erlenmeyer flasks and $\mathrm{pH}$ was set at 10 . The experiments were performed at $80{ }^{\circ} \mathrm{C}$. Then, the $\mathrm{UV}-\mathrm{V}$ is spectrum was taken after $10,25,45,65$, 100, 1020 and $1320 \mathrm{~min}$, respectively. According to the results, the best time for nanoparticles synthesis was determined.

\section{Characterization \\ of the green synthesized silver nanoparticles}

It has been reported that the nanoparticles size and shape mainly depend on different factors like concentration of leaf extract, salt solution, $\mathrm{pH}$ and temperature. ${ }^{31,32}$ In order to characterize silver nanoparticles by SEM, XRD, TEM and FTIR devices, according to obtained results from the UV-Vis spectra for the studied optimal parameters (Figures 3-7), silver nanoparticles were resynthesized at the following conditions: $\mathrm{pH}=10$, Dermaneh extract volume $=8 \mathrm{ml}$, salt solution concentration $=0.01 \mathrm{M}$, temperature $=80{ }^{\circ} \mathrm{C}$, time $=1020 \mathrm{~min}$. After a suitable time, to separate the metallic nanoparticles sediment from solution, the sample was centrifuged. Then, metallic nanoparticles were characterized by abovementioned methods after washing and drying. 


\section{RESULTS AND DISCUSSION}

The UV-Vis spectra show the effect of different optimal parameters on silver nanoparticles synthesis by Dermaneh extract. Metal-based nanoparticles have many free electrons leading to the surface plasmon resonance (SPR) effect when excited with light of specific wavelengths. The yielded spectrum records vibrations of the free electrons of nanoparticles. In this work, the high peak which is appeared in the visible area also confirms the formation of silver nanoparticles and SPR absorption band was observed at $420 \mathrm{~nm}$ wavelength region due to the presence of brown-colored synthesized silver nanoparticles (Figures 3-7). Similar results were reported by Muhammad Amin et al. ${ }^{33}$

\section{Effect of pH on silver nanoparticle synthesis}

$\mathrm{pH}$ is another major factor affecting the reduction of silver ions, that is shown in Fig. 3. According to obtained results from the UV-Vis spectra, at $\mathrm{pH}=2$ and $\mathrm{pH}=4$, no absorption peaks were observed in the range of $400-600 \mathrm{~nm}$ for the samples after $30 \mathrm{~min}$ of the reaction. An absorption band appeared at about $440 \mathrm{~nm}$ when $\mathrm{pH}$ increased from 4 to 8, indicating the formation of Ag-NPs. Upon a further increase in $\mathrm{pH}$ (up to 10), a redshift appeared from $406 \mathrm{~nm}$ to $550 \mathrm{~nm}$ and then a decrease occurred. This behavior may be due to the ionization of phenolic compounds and tannins in the extract of Dermaneh.$^{34}$ It was observed that the absorption peak intensity increased gradually with an increase in $\mathrm{pH}$, suggesting that the reduction rate of silver ions increases with the increase in $\mathrm{pH}$. According to the Fig. 3, the formation of AgNPs was repressed by acidic conditions and raised by basic conditions. At lower $\mathrm{pH}(\mathrm{pH}=5)$, larger silver nanoparticles were formed, whereas, smaller and highly dispersed silver nanoparticles were formed at higher $\mathrm{pH}^{33}$. Thus, $\mathrm{pH}=10$ was selected as an optimum $\mathrm{pH}$.

\section{Effect of Dermaneh extract volume}

From Fig. 4, it can be seen that by increasing the extract volume of Dermaneh, the SPR bands became sharper and for all samples the band appeared at $420 \mathrm{~nm} .{ }^{35}$ This occurred by increasing the extract volume of Dermaneh, leading to an increase in the concentration of tannins, phenolics, alkaloids and sugars, etc. which is responsible for the forming and stabilizing of silver nanoparticle.
So, the extract volume of Dermaneh was selected $8 \mathrm{~mL}$.

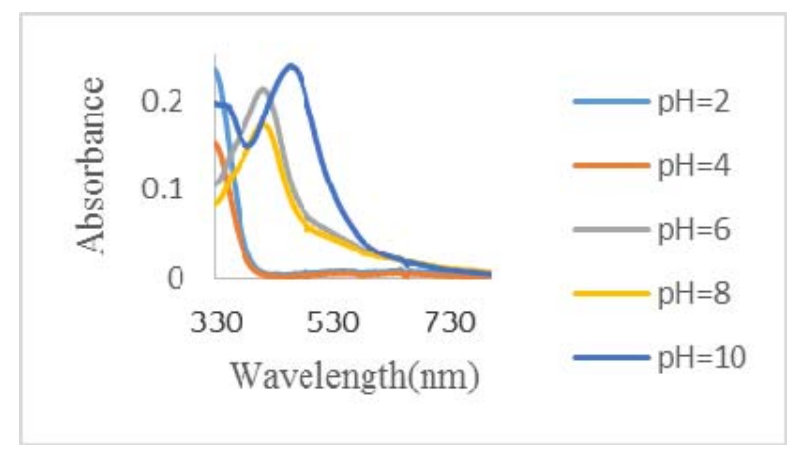

Fig. 3 - Effect of $\mathrm{pH}$ on Silver nanoparticles synthesis by Dermaneh extract $(5 \mathrm{ml}$ of extract solution, $95 \mathrm{ml}$ of $0.001 \mathrm{M}$ Silver nitrate, time: $30 \mathrm{~min}$, stirring rate $150 \mathrm{rpm}$ ).

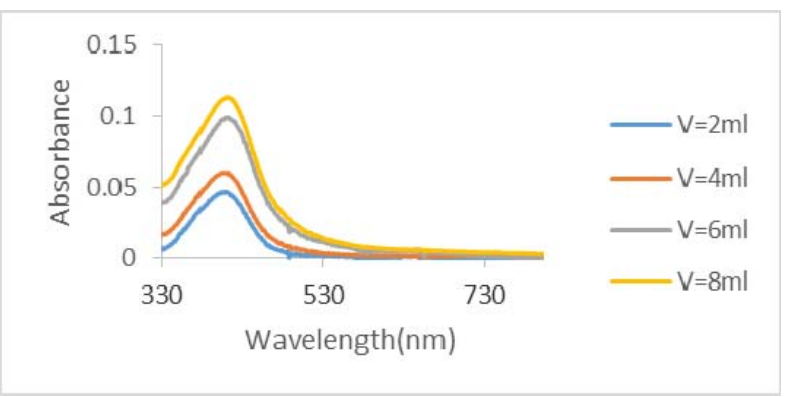

Fig. 4 - Effect of Dermaneh extract solution on Silver nanoparticles synthesis $(\mathrm{pH}$ of the solution was $10,95 \mathrm{ml}$ of $0.001 \mathrm{M}$ Silver nitrate, time: $30 \mathrm{~min}$, stirring rate $150 \mathrm{rpm}$ ).

\section{Effect of metal salt concentration}

According to Fig. 5, the obtained results from UV-Vis spectra showed that by increasing the metal salt concentration, the SPR bands for all samples appeared at $416 \mathrm{~nm}$ and became sharper thus smaller and highly dispersed silver nanoparticles were formed. Similar results have already been reported on the effect of metal salt concentration on the formation of metal nanoparticles. ${ }^{35}$ The required concentration of silver nitrate for the improvement of reaction was selected $0.01 \mathrm{M}$.

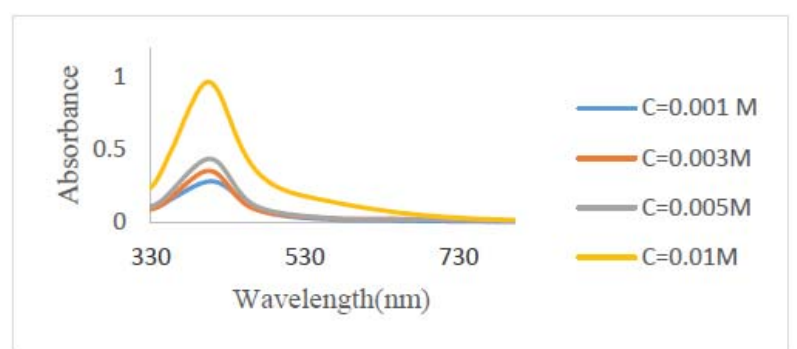

Fig. 5 - Effect of nitrate solution concentration on Silver nanoparticles synthesis by Dermaneh extract $(\mathrm{pH}$ of the solution was $10,8 \mathrm{ml}$ of the Dermaneh extract, time: $30 \mathrm{~min}$, stirring rate $150 \mathrm{rpm}$ ). 


\section{Effect of temperature}

Fig. 6 shows the UV-Vis spectra regarding the effect of temperature on the synthesis of silver nanoparticles using Dermaneh extract at different temperatures. It can be clearly seen that as the temperature of reaction increased, the SPR bands became sharper. The results from the four mentioned temperatures showed a similar response, with a variation in the maximum. Similar results were reported by Piñero et al. ${ }^{36}$ According to the obtained results, $80{ }^{\circ} \mathrm{C}$ was selected as the optimum temperature for this study.

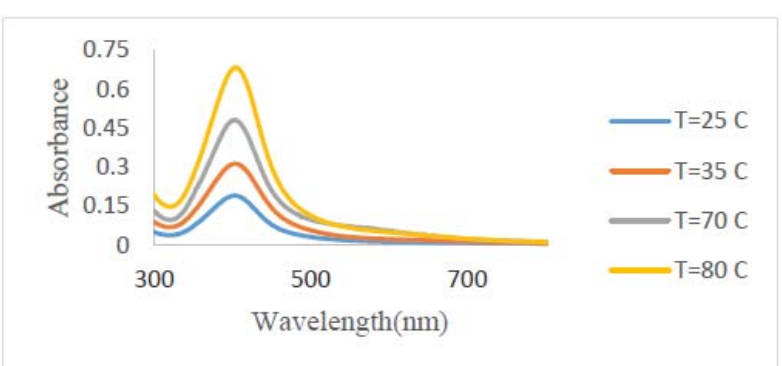

Fig. 6 - Effect of temperature on Silver nanoparticles synthesis by Dermaneh extract $(\mathrm{pH}$ of the solution was $10,8 \mathrm{ml}$ of the Dermaneh extract, $0.01 \mathrm{M}$ Silver nitrate, time: $30 \mathrm{~min}$, stirring rate $150 \mathrm{rpm})$.

\section{Effect of time}

The effect of time on biosynthesis of Ag-NPs using Dermaneh extract can be seen by UV-Vis spectra reported in Fig. 7. A small weak and broad peak appeared at $408 \mathrm{~nm}$ after $10 \mathrm{~min}$ of stirring, indicating that few nanoparticles were formed. By increasing the time from $10 \mathrm{~min}$ to $20,45,65,100$ and $1020 \mathrm{~min}$, absorption bands became sharper and sharper and a clearly visible peak after 1020 min at $411 \mathrm{~nm}$ was observed (Fig. 7) due to the enhanced formation rate of Ag-NPs. Thus, the optimum time for the improvement of reaction was considered $1020 \mathrm{~min}$, which is in accordance with previous reports. $^{37,38}$

\section{SEM analysis}

The surface morphological characterizations of silver nanoparticles were done using SEM (KYKY-EM3200 ). In Fig. 8, SEM image clearly confirmed the presence of poly-dispersed and spherical shape of silver nanoparticles with a size of $41-88 \mathrm{~nm}$. The results obtained from SEM analysis were very similar to the findings of other researchers. ${ }^{39-41}$

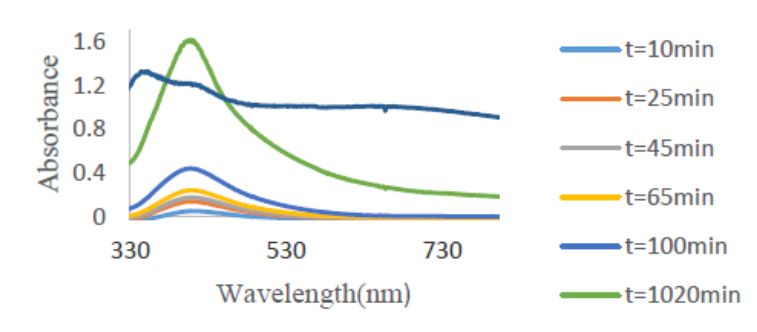

Fig. 7 - Effect of time on Silver nanoparticles synthesis by Dermaneh extract ( $\mathrm{pH}$ of the solution was $10,8 \mathrm{ml}$ of the Dermaneh extract, $0.01 \mathrm{M}$ Silver nitrate, temperature $80^{\circ} \mathrm{C}$, stirring rate $150 \mathrm{rpm}$ ).

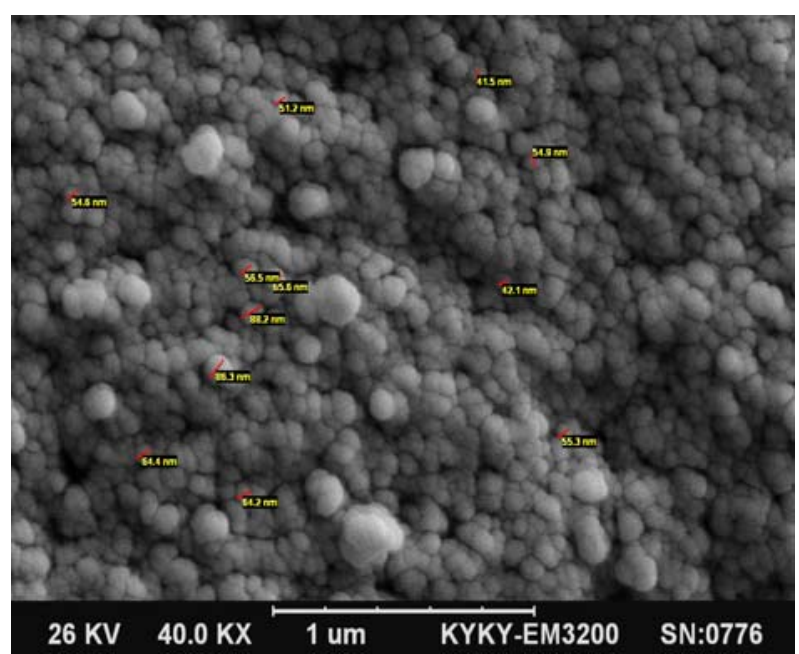

Fig. 8 - SEM image of AgNPs synthesized using by Dermaneh extract.

\section{XRD analysis}

X-ray diffraction (XRD) analyses were carried out with a GNR MPD 3000 made Italy diffractometer using a $\mathrm{Cu}$ anode $(\lambda=1.54056 \AA)$. The diffractograms were recorded at $2 \theta$ in the range $9^{\circ}-80^{\circ}$, with counting time 0.5 seconds and step size of $0.02^{\circ}$. In Fig. 9, the XRD pattern clearly shows cubic structure which matches the values (38.4389), (44.5207), (64.7785), (77.7046) corresponded to the hkl planes (llll), $\left.1 \begin{array}{lll}2 & 0 & 0\end{array}\right),\left(\begin{array}{ll}2 & 2\end{array}\right.$ $0)$, (3 1 1), respectively. All the peaks matched well with the standard JCPDS file 87-0717. The appearance of sharp peaks indicated the crystalline nature of the synthesized AgNPs. There were four peaks with a low intensity at around $29.9^{\circ}, 32.4^{\circ}$, $48.8^{\circ}$ and $56.8^{\circ}$ (Fig. 9), confirming the formation of a small amount of $(\mathrm{AgCl})$ impurities. Similar results have been reported by $\mathrm{Babu}$ et al., ${ }^{39}$ Tippayawat et al. ${ }^{40}$ and Meena and Chouhan. ${ }^{42}$

The Debye-Scherrer equation was applied to determine average crystallite diameter size from 
the full width at half-maximum of the diffraction peaks:

$$
\mathrm{D}=K \lambda / \beta \cos \theta
$$

where $\mathrm{D}$ is the crystallite diameter size in $\mathrm{nm}$, $\lambda$ - denotes $\mathrm{X}$-ray wavelength, $\beta$ - is full width at half-maximum (FWHM), and $\theta$ - is Bragg's angle of reflection. Average size of the biosynthesized nanoparticles was found to be about $20 \mathrm{~nm}$. Table 1 represents the sharper peaks details for silver nanoparticles size calculation.

Table 1

Crystal parameters of AgNPs synthesized by Dermaneh extract in XRD pattern

\begin{tabular}{cccccc}
\hline No. & $\begin{array}{c}\text { Position } \\
{\left[{ }^{\circ} \mathbf{2} \text { Theta] }\right.}\end{array}$ & $\begin{array}{c}\text { FWHM } \\
{\left[{ }^{\circ} \mathbf{2} \text { Theta] }\right.}\end{array}$ & h k l & $\begin{array}{c}\text { d-spacing } \\
\left({ }^{\circ} \mathbf{A}\right)\end{array}$ & $\begin{array}{c}\text { size } \\
(\mathbf{n m})\end{array}$ \\
\hline $\mathbf{1}$ & 38.4389 & 0.4133 & 111 & 2.35888 & 21.25 \\
$\mathbf{2}$ & 64.7785 & 0.4723 & 220 & 1.44451 & 20.80 \\
$\mathbf{3}$ & 77.7046 & 0.5760 & 311 & 1.23188 & 18.49 \\
& & & & Ave. $=20.18$ \\
\hline
\end{tabular}

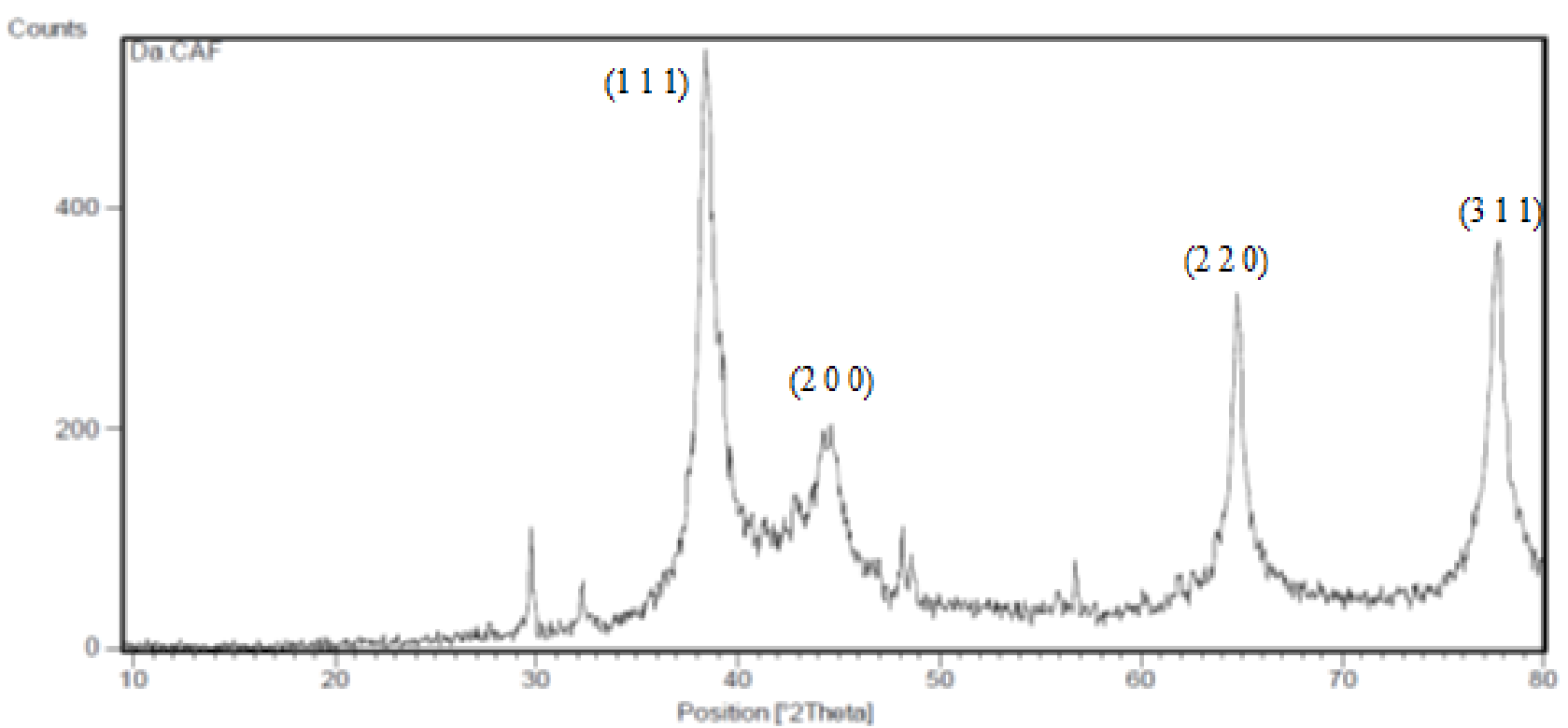

Fig. 9 - X-ray diffractograms of Silver nanoparticles synthesized using by Dermaneh extract.

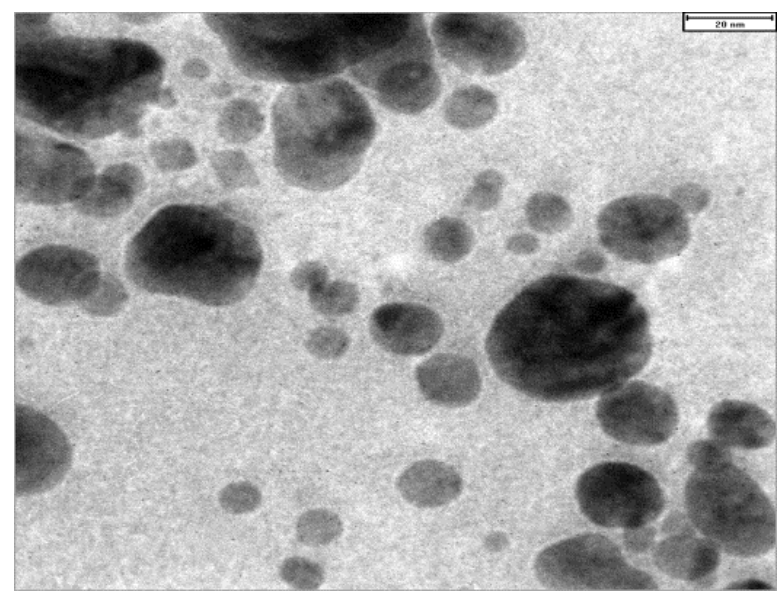

Fig. 10 - TEM image showing shape and size characteristics of AgNPs synthesized at the optimized condition. 


\section{TEM analysis}

TEM measurements were performed on Philips, Model CM120 instrument operated at an accelerating voltage $120 \mathrm{kV}$. The TEM images of colloid nanoparticles are shown in Figure 10. It is observed that the morphology of nanoparticles is often polydispersed, spherical and cubic, which is in settlement with the shape of the SPR band in the UV-Vis spectra. The average particle size calculated for nanoparticles was $20 \mathrm{~nm}$. This result is in agreement with the shape of the SPR band as well as the particle size calculated from XRD analysis.

\section{FTIR analysis}

Fourier transform infrared (FTIR) spectra of the samples were obtained using Perkinelmer
Spectrum 2, in the diffuse reflectance mode operating at a resolution of $4 \mathrm{~cm}^{-1}$ in $\mathrm{KBr}$ pellets. FTIR spectra of Dermaneh extracts taken before and after synthesis of silver nanoparticles were analyzed in terms of the possible functional groups responsible for the formation of silver nanoparticles. FTIR spectra were obtained to identify the possible biomolecules in the plant extract responsible for predicting their role in nanoparticle synthesis and the reduction of silver ions as well as the capping agents responsible for the stability of biogenic nanoparticle solution. The FTIR spectra indicated the existence of various functional groups at different positions. Figs. 11(a) and 11(b) show the FTIR spectra of plant extract before and after synthesis, representing prominent absorption band at around $3413 \mathrm{~cm}^{-1}, 1619,1348$, $1080,797,485 \mathrm{~cm}^{-1}$.

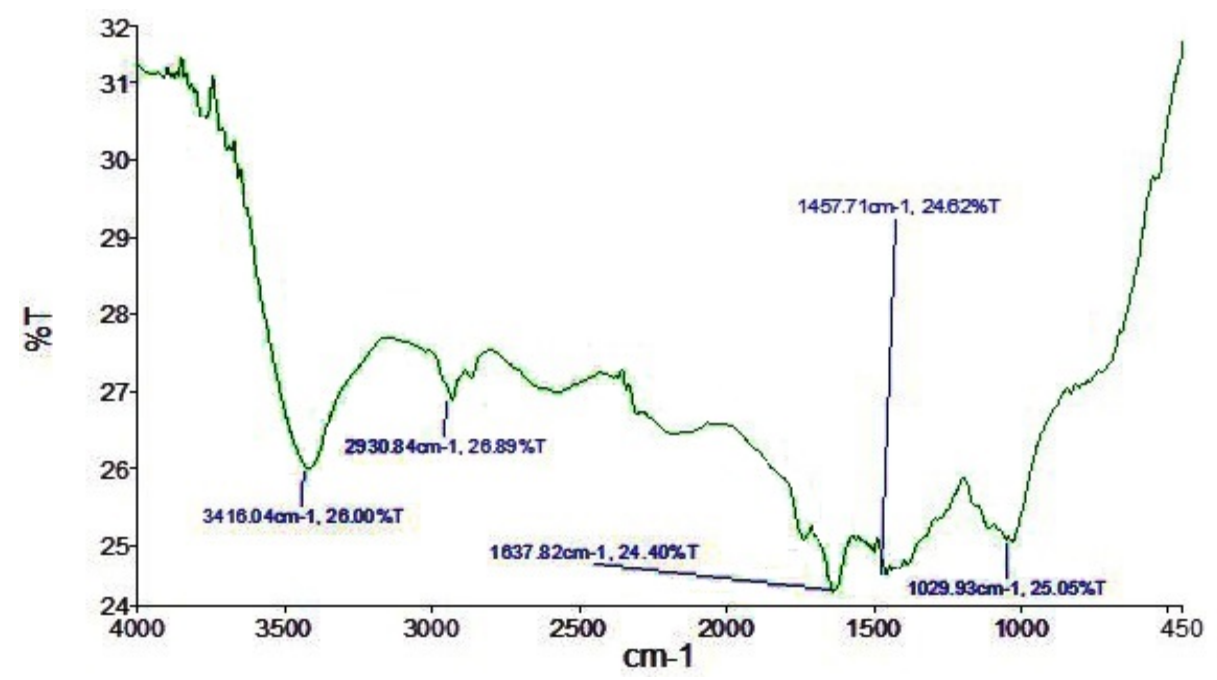

(a)

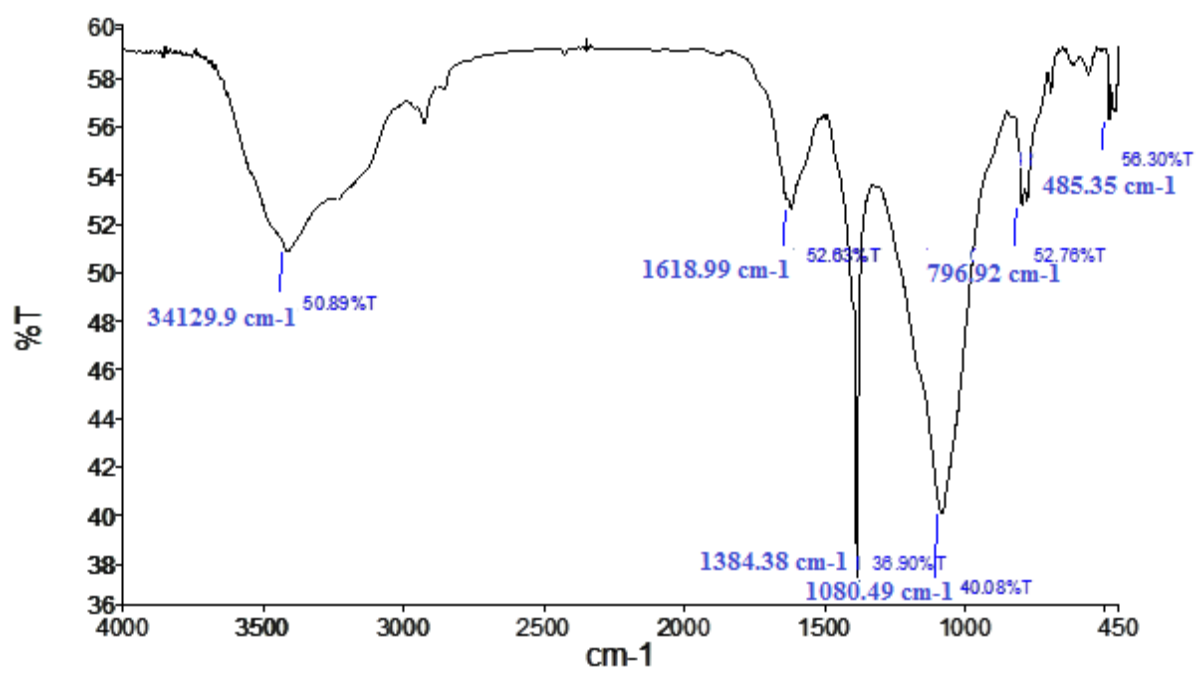

(b)

Fig. 11 - FT-IR spectroscopy of (a) Dermaneh extract (b) Silver nanoparticles synthesized using by Dermaneh extract. 
Table 2

List of the work related AgNPs synthesis using plant extract

\begin{tabular}{|c|c|c|c|c|c|c|c|}
\hline Plant extraxt & Author & $\begin{array}{l}\text { Operating } \\
\text { Conditions }\end{array}$ & Characterization & $\begin{array}{l}\text { Size } \\
(\mathrm{nm})\end{array}$ & shape & $\begin{array}{l}\text { Crystal } \\
\text { Structure }\end{array}$ & $\begin{array}{l}\text { Year/ } \\
\text { Ref. }\end{array}$ \\
\hline $\begin{array}{l}\text { Cheilanthes } \\
\text { forinosa Forsk }\end{array}$ & Nalwade et al. & $\begin{array}{l}1 \mathrm{mM}, 4 \mathrm{hr}, \\
\text { room temp. } \\
10 \mathrm{~mL} / 90 \mathrm{~mL}\end{array}$ & $\begin{array}{l}\text { UV-Vis } \\
\text { SEM,XRD }\end{array}$ & $\sim 26.58$ & sph. & FCC & $\begin{array}{l}(2013) \\
{[46]}\end{array}$ \\
\hline $\begin{array}{l}\text { Nephrolepis } \\
\text { sexaltata L. fern }\end{array}$ & Bhor et al. & $\begin{array}{l}1 \mathrm{mM}, 4 \mathrm{~h}, \\
10 \mathrm{~mL} / 90 \mathrm{~mL}\end{array}$ & $\begin{array}{l}\text { UV-Vis } \\
\text { SEM,XRD }\end{array}$ & avg 24.76 & sph. & FCC & $\begin{array}{l}(2014) \\
{[47]}\end{array}$ \\
\hline $\begin{array}{l}\text { Gelidiella } \\
\text { acerosa }\end{array}$ & Vivek et al. & $\begin{array}{l}1 \mathrm{mM} \text {, room } \\
\text { temp, } \\
10 \mathrm{~mL} / 90 \mathrm{~mL}\end{array}$ & $\begin{array}{l}\text { UV-Vis } \\
\text { FTIR,SEM } \\
\text { TEM,XRD }\end{array}$ & $\sim 22 \mathrm{~nm}$ & sph. & FCC & $\begin{array}{l}(2011) \\
{[48]}\end{array}$ \\
\hline $\begin{array}{l}\text { Caulerpa } \\
\text { racemosa } \\
\text { marine algae }\end{array}$ & $\begin{array}{l}\text { Kathiraven et } \\
\text { al. }\end{array}$ & $\begin{array}{l}1 \mathrm{mM}, 3 \mathrm{hr} \text {, } \\
\text { room temp. } \\
10 \mathrm{~mL} / 90 \mathrm{~mL}\end{array}$ & $\begin{array}{l}\text { UV-Vis } \\
\text { FTIR,TEM } \\
\text { XRD }\end{array}$ & $5-25$ & sph, tri. & FCC & $\begin{array}{l}(2014) \\
{[49]}\end{array}$ \\
\hline Ulva fasciata & Rajesh et al. & $\begin{array}{l}1 \mathrm{mM}, 2 \mathrm{~min} \text {, } \\
\text { room temp. } \\
3 \mathrm{~mL} / 100 \mathrm{~mL}\end{array}$ & $\begin{array}{l}\text { UV-Vis } \\
\text { FTIR,SEM } \\
\text { XRD,EDX }\end{array}$ & $28-41$ & $\mathrm{sph}$ & cryst & $\begin{array}{l}(2012) \\
{[50]}\end{array}$ \\
\hline $\begin{array}{l}\text { Abutilon } \\
\text { indicum leaf }\end{array}$ & $\begin{array}{l}\text { Ashokkumar } \\
\text { et al. }\end{array}$ & $\begin{array}{l}10 \mathrm{mM}, 15 \mathrm{~min} \text {, } \\
\text { room temp. } \\
2 \text { to } 3.5 \mathrm{~mL} / 30 \\
\mathrm{~mL},\end{array}$ & $\begin{array}{l}\text { UV-Vis } \\
\text { FTIR, FS } \\
\text { FE-SEM } \\
\text { TEM,XRD }\end{array}$ & $7-17$ & sph. & FCC & $\begin{array}{l}(2015) \\
{[51]}\end{array}$ \\
\hline $\begin{array}{l}\text { Pistacia } \\
\text { atlantica }\end{array}$ & Sadeghi et al. & $\begin{array}{l}1 \mathrm{mM}, 35 \mathrm{~min} \text {, } \\
\text { room temp. } \\
1 \mathrm{~mL} / 10 \mathrm{~mL}\end{array}$ & $\begin{array}{l}\text { UV-Vis } \\
\text { FTIR } \\
\text { SEM,TEM } \\
\text { XRD, ZP } \\
\text { EDAX }\end{array}$ & $10-50$ & sph. & FCC & $\begin{array}{l}(2015) \\
{[52]}\end{array}$ \\
\hline $\begin{array}{l}\text { Ziziphora } \\
\text { tenuior }\end{array}$ & $\begin{array}{l}\text { Sadeghi and } \\
\text { Gholamhosein } \\
\text { poor }\end{array}$ & $\begin{array}{l}0.1 \mathrm{mM}, 35 \\
\text { min, room } \\
\text { temp. }\end{array}$ & $\begin{array}{l}\text { UV-Vis } \\
\text { FTIR, ZP } \\
\text { SEM-EDAX } \\
\text { TEM,XRD }\end{array}$ & $8-40$ & sph. & FCC & $\begin{array}{l}(2015) \\
{[53]}\end{array}$ \\
\hline $\begin{array}{l}\text { Delphinium } \\
\text { denudatum }\end{array}$ & Suresh et al. & $\begin{array}{l}1 \mathrm{mM}, 2 \mathrm{hr} \\
\text { room temp. } \\
1.5 \mathrm{~mL} / 30 \mathrm{~mL}\end{array}$ & $\begin{array}{l}\text { UV-Vis } \\
\text { FTIR,FESEM } \\
\text { XRD }\end{array}$ & $<85 \mathrm{~nm}$ & sph. & FCC & $\begin{array}{l}(2014) \\
{[54]}\end{array}$ \\
\hline $\begin{array}{l}\text { Myrmecodia } \\
\text { pendan }\end{array}$ & Zuas et al. & $\begin{array}{l}2.5 \mathrm{mM} \text {, room } \\
\text { temp. } \\
0.3 \mathrm{~mL} / 60 \mathrm{~mL}\end{array}$ & $\begin{array}{l}\text { UV-Vis } \\
\text { FTIR, XRD } \\
\text { SEM,TEM }\end{array}$ & $10-20$ & sph. & FCC & $\begin{array}{l}(2014) \\
{[55]}\end{array}$ \\
\hline $\begin{array}{l}\text { Tinospora } \\
\text { cordifolia stem } \\
\text { powder. }\end{array}$ & $\begin{array}{l}\text { Anuj and } \\
\text { Ishnava }\end{array}$ & $\begin{array}{l}1 \mathrm{mM}, 30 \mathrm{~min} \text {, } \\
\text { room temp. } \\
40 \mathrm{~mL} / 200 \mathrm{~mL}\end{array}$ & $\begin{array}{l}\text { UV-Vis } \\
\text { FTIR,TEM } \\
\text { XRD,EDAX }\end{array}$ & 60 & sph. & cryst & $\begin{array}{c}(2013) \\
{[56]}\end{array}$ \\
\hline Aloe leaf & Zhang et al. & $\begin{array}{l}0.1-1.5 \mathrm{mM}, \\
20 \mathrm{~min}, \\
20-40{ }^{0} \mathrm{C}, \\
0 \text { to } 15 \mathrm{~mL} / 1 \\
\mathrm{~mL}\end{array}$ & $\begin{array}{l}\text { UV-Vis } \\
\text { TEM,XRD }\end{array}$ & $\sim 20$ & sph. & FCC & $\begin{array}{l}(2013) \\
{[57]}\end{array}$ \\
\hline $\begin{array}{l}\text { Azadirchata } \\
\text { indica(neem) }\end{array}$ & $\begin{array}{l}\text { Kirubaharan et } \\
\text { al. }\end{array}$ & $\begin{array}{l}1 \mathrm{mM}, 90 \mathrm{~min}, \\
\text { room to } 90{ }^{\circ} \mathrm{C} \text {, } \\
1.25 \mathrm{~mL} / 50 \mathrm{~mL}\end{array}$ & $\begin{array}{l}\text { UV-Vis } \\
\text { TEM,XRD }\end{array}$ & $15-20$ & sph. & FCC & $\begin{array}{l}(2012) \\
{[58]}\end{array}$ \\
\hline $\begin{array}{l}\text { Artemisia sieberi } \\
\text { Besser } \\
\text { (Dermaneh) }\end{array}$ & $\begin{array}{l}\text { Rousta and } \\
\text { Ghasemi }\end{array}$ & $\begin{array}{l}\text { o.o1M, } \\
1020 \mathrm{~min}, 80{ }^{0} \mathrm{C} \\
8 \mathrm{~mL} / 95 \mathrm{~mL}\end{array}$ & $\begin{array}{l}\text { UV- Vis } \\
\text { SEM, FTIR } \\
\text { XRD, TEM }\end{array}$ & $\sim 20$ & sph. & FCC & $\begin{array}{l}\text { This } \\
\text { study }\end{array}$ \\
\hline
\end{tabular}

Note: Sph—spherical, Tri—Triangular, FCC—Face centered cubic, Cryst—Crystalline. 
The peaks in the region $3412 \mathrm{~cm}^{-1}$ were assigned to $\mathrm{O}-\mathrm{H}$ stretching vibration, indicating the presence of hydroxyl groups such as alcohol and phenol compounds and aldehyde - $\mathrm{C}-\mathrm{H}-$ stretching of alkanes while the peaks around $1619 \mathrm{~cm}^{-1}$ were assigned to $\mathrm{C}=\mathrm{O}$ stretching vibrations or stretching of alkenes. The peaks in the regions $1348 \mathrm{~cm}^{-1}$ to $830 \mathrm{~cm}^{-1}$ corresponded to $-\mathrm{C}-\mathrm{N}$ - stretching vibration of amines or -C-O stretching of alcohols, ethers, carboxylic acids and anhydrides. Absorption band at $1080 \mathrm{~cm}^{-1}$ could be assigned to the $\mathrm{C}-\mathrm{OH}$ stretching vibrations of primary alcohol groups in the Dermaneh extracts. The absorption band around $485 \mathrm{~cm}^{-1}$ is indicated the presence of alkyl halides ${ }^{43}$. The presence of absorption bands in the Dermaneh extract spectrum and absence of the same peak in the silver nanoparticle spectrum indicated the involvement of Dermaneh extract in the synthesis of the silver nanoparticles. According to the Figs. 11(a) and 11(b), the shift from higher to lower wave numbers in comparison with the two figures indicated the fabcilitation resonance for the binding and reduction of silver nanoparticles surface. ${ }^{44}$

The appearance of biomolecules in the plant extract (such as flavonoids) confirmed their responsibility for the reduction, capping and stabilization of the newly formed nanoparticles in agreement with literature data. ${ }^{45}$

Finally, the synthesis of silver nanoparticles using different plants was compared to the current study (Table 2). It can be observed that silver nanoparticles were successfully synthesized using Dermaneh extract.

\section{CONCLUSION}

In this study, a rapid and eco-friendly synthesis method of silver nanoparticles (Ag-NPs) by Artemisia Sieberi Besser (Dermaneh) leaf extract was proposed. The plant extract contained abundant natural biomolecules such as flavonoids and flavones that might play a major role in biosynthesis of Ag-Ps. Different parameters affecting nanoparticles formation and growth such as $\mathrm{pH}$, volume of the extract, silver ion concentration, temperature and time were monitored by UV-Vis spectrophotometer. The synthesized silver nanoparticles were characterized by UV-visible spectroscopy, SEM, XRD, TEM analyses. The formation of silver nanoparticles was confirmed by clearly observing the color change from yellow to brown and corroborated by UVvisible (surface plasmon resonance) analysis. The results of XRD pattern, SEM and TEM images confirmed the successful synthesis of silver nanoparticles in terms of crystalline nature and morphology (poly-dispersed, spherical and cubic shapes) with an average size of $20 \mathrm{~nm}$. The biomolecules like flavonoids and flavones available in the Dermaneh extract, which were responsible for reduction of silver ions to silver nanoparticles, were revealed in FT-IR studies. The results of this study confirmed that green synthesis is an effective and eco-friendly method for producing silver nanoparticles.

\section{REFERENCES}

1. V. Mozaffarian, "A Dictionary of Iranian Plants Names", FarhangMoaser, Tehran, Iran, 1999.

2. H. A. A. Twaij and A. A. Al-Badr, J. Ethnopharmacol., 1988, 24, 123-126.

3. B. Behmanesh, G. A. Heshmati, M. Mazandarani, M. B. Rezaei, A. R. Ahmadi, E. O. Ghaemi and S. Bakhshandeh Nosrat, Asian J. Plant Sci., 2007, 6, 562-564.

4. M. Mahboubi and N. Farzin, Iranian J. Microbiol., 2009,1, 43-48.

5. M. Farzaneh, H. Ghorbani-Ghouzhdi, M. Ghorbani and J. Hadian, Pakistan. J. Biol. Sci., 2006, 9, 1979-1982.

6. A. R. Khosravi, H. Shokri, M. H. Darabi, A. Kashani, P. Mansouri and A. Naser, J. Mycol. Méd., 2009, 19, 17-21.

7. F. Rad, F. Aala, N. Reshadmanesh and R. Yaghmaie, Indian J. Dermatol., 2008, 53, 115-118.

8. P. Mansouri, M. Kashanian, R. Bekhradi and H. Hakmat, Iranian J. Pharmaceut. Res., 2004, 2, 38-38.

9. A. A. S. Sefidgar, A. A. Moghadamnia, A. AkhavanTafti, M. Sahebjami, M. Heydari and M, Motallebnejad, Caspian J. Internal. Med., 2010, 47-49.

10. A. Morshedi, M. H. Dashti Rahmatabadi, M. Dehghan Harati, M. A. BagheriaNasab and S. Salami, J. Med. Plants., 2011, 10, 48-57.

11. M. Negahban, S. Moharramipour and F. Sefidkon, AsiaPacific Entomol., 2006, 9, 61-66.

12. M. Negahban, S. Moharramipour and F. Sefidkon, J. Stored. Prod. Res., 2007, 43, 123-128.

13. F. Yarahmadi, A. Rajabpour, N. ZandiSohani and L. Ramezani, Avicenna J. Phytomed., 2013, 3, 106-111.

14. A. Salahi Ardakani and S. Parhizkar, Int. J. Med. Arom. Plants., 2012, 2, 596-602.

15. A. J. Marco, J. F. Sanz-Cervera, F. Sancenon, J. Jakopuvic, A. Rustaiyan and F. Mohamadi, Phytochemistry, 1993, 34, 1061-1065.

16. P. Weyerstahl, S. Schneider, H. Marschall and A. Rustaiyan, Liebigs Annalen der Chemie, 1993, 2, 111-116.

17. H. A. Arab, S. Rahbari, A. Rassouli, M. H. Moslemi and F. Khosravirad, Trop. Anim. Health Prod., 2006, 38, 497-503.

18. E. K. Elumalai, T. N. V. K. V. Prasad, V. Kambala, P. C. Nagajyothi and E. David, Arch. Appl. Sci. Res., 2010, 2, 76-81.

19. M. Gericke and A. Pinches, Gold Bull., 2006, 39, 22-28.

20. D. Mandal, M. E. Bolander, D. Mukhopadhyay, S. Sankar and P. Mukherjee, Appl. Microbiol. Biotechnol., 2006, $69,485-492$. 
21. S. Rajeshkumar, C. Kannan and G. Annadurai, Int. J. Pharm. Bio. Sci., 2012, 3, 502 - 510.

22. S. Rajeshkumar, C. Kannan and G. Annadurai, Drug Invention Today, 2012, 4, 511-513.

23. K. S. Hemath Naveen, G. Kumar, L. Karthik and K. V. Bhaskara Rao, Arch. Appl. Sci. Res., 2010, 2, 161-167.

24. N. Ahmad, S. Sharma, M. Alama, V. N. Singh, S. F. Shamsid, B. R. Mehta and A. Fatma, Colloids Surf. B: Biointerf., 2010, 8,181-86.

25. G. D. Gnanajobitha, G. Annadurai and C. Kannan, Int. J. Pharma. Sci. Res., 2012, 3, 323-330.

26. J. Anarkali, D.Vijaya Raj, K. Rajathi and S. Sridhar, Arch. Appl. Sci. Res., 2012, 4, 1436-1441.

27. N. C. J. Packia Lekshmi, S. Benarcin Sumi, S. Viveka, S. Jeeva and J. Raja Brindha, J. Microbiol. Biotech. Res., 2012, 2, 115-119.

28. J. L. Gardea-Torresdey, E. Gomez, J. Peralta-Videa, J. G. Parsons and H. E. Troiani, Nano Lett., 2002, 2, 397-401.

29. M. Singh, S. Singh, S. Prasad and I. S. Gambhir, Digest J. Nanomater. Biostruct., 2008, 3, 115-122.

30. M. Rai, A. Yadav and A. Gade, Biotechnol. Advances., 2009, 27, 76-83.

31. V. Armendariz, I. Herrera, J. R. Peralta-Videa, M. JoseYacaman et al., J. Nanopart. Res., 2004, 6, 377-82.

32. A. Rai , A. Singh, A. Ahmad and M. Sastry, Langmuir., 2006, 22, 736- 41

33. A. Muhammad, A. Farooq, R. Muhammad, M. Saeed Ashraf Janjua, I. Awais and U. Rashid, Int. J. Mol. Sci., 2012, 13, 9923-9941.

34. R. Heydari and M. Rashidipour, Int. J. Breast Cancer, 2015, doi.org/10.1155/2015/846743.

35. S. A. Umoren,I. B. Obot and Z. M. Gasem, J. Mater. Environ. Sci., 2014, 5, 907-911.

36. S. Piñero, S. Camero and S. Blanco, J. Physics: Conference Series., 2017, 786, 1-8.

37. R. Bo and T. Ren-Cheng, Adv. Nat. Sci.: Nanosci. Nanotechnol., 2017, 8, 1-7.

38. A. Tausif, I. Muhammad and A. Mohamad, Procedia Engineering., 2016,148, $467-472$.

39. S. Ananda Babu and H. Gurumallesh Prabu, Materials Letters., 2011, 65, 1675-1677.

40. P. Tippayawat, N. Phromviyo, P. Boueroy and A. Chompoosor, PeerJ, 2016, DOI 10. (2016) 7717/peerj.2589.
41. R. Arunachalam, S. Dhanasingh, B. Kalimuthu, M. Uthirappan, C. H. Rose and A. Mandal, Colloids and Surfaces B: Biointerfaces., 2012, 94, 226- 230.

42. P. K. Meena and N. Chouhan, Research J. Recent Scie., $\mathbf{2 0 1 5}, 4,47-52$.

43. A. Arunachalam, S. Thomas, N. A. Jose and C. H. V. Lyza, World Applied Scie. J., 2011, 113, 1833-1840.

44. N. N. Bonnia, M. S. Kamaruddin, M. H. Nawawi, S. Ratim, H. N. Azlina and E. S Ali, Procedia Chem., 2016, 19, $594-602$.

45. A. A. Abimbola, "Green synthesis of capped silver nanoparticles and their hybrids: antimicrobial and optical properties", $P h D$ thesis, 2017, Covenant University, Ota, Nigeria.

46. A. R. Nalwade, M. N. Badhe, C. B. Pawale and S. B. Hinge, J. Biol. Tech., 2013, 4, 12-18.

47. G. Bhor, S. Maskare, S. Hinge, L. Singh and A. Nalwade, Asian J. Pharma. Tech. Innovation., 2014, 2-12.

48. M. Vivek, P. S. Kumar, S. Steffi and S. Sudha, Avicenna J. Med. Biotechn., 2011, 3, 143-148.

49. T. Kathiraven, A. Sundaramanickam, N. Shanmugam, and T. Balasubramanian, Appl. Nanoscie., 2014, 5, 499-504.

50. S. Rajesh, D. P. Raja, J. M. Rathi and K. Sahayaraj, J. Biopesticides, 2012, 5, 119-128.

51. S. Ashokkumar, S. Ravi, V. Kathiravan and S. Velmurugan, Spectrochim. Acta A., 2015, 134, 34-39.

52. B. Sadeghi, A. Rostami and S. S. Momeni, Spectrochim. Acta A., 2015, 134, 326-332.

53. B. Sadeghi and F. Gholamhoseinpoor, Spectrochim. Acta A., 2015, 134, 310-315.

54. P. Suresh, P. H. Gunasekar, D. Kokila, D. P. Rabhu, D. Dinesh, N. Ravichandran, B. Ramesh, A. Koodalingam and G. V. Siva, Spectrochim. Acta A., 2014, 127, 61-66.

55. O. Zuas, N. Hamim and Y. Sampora, Mater. Lett., 2014, 123, 156-159.

56. S. A. Anuj and K. B. Ishnava, Int. J. Pharm. Biolog. Scie., 2013, 4, 849-863.

57. Y. Zhang, X. Cheng, Y. Zhang, X. Xue and Y. Fu, Colloid. Surface. A., 2013, 423, 63-68.

58. C. J. Kirubaharan, D. Kalpana, Y. S. Lee, A. R. Kim, D. J. Yoo, K. S. Nahm and G. G. Kumar, Industrial Eng. Chem. Research., 2012, 51, 7441-7446. 